\title{
PENINGKATAN PEMAHAMAN MAHASISWA PRODI ILMU HUKUM TERHADAP PERDA NOMOR 5 TAHUN 2011 TENTANG PAJAK RESTORAN DI UNIVERSITAS AL WASHLIYAH (UNIVA) MEDAN
}

\author{
Muhlizar, SH, MM, MH \\ Dosen Tetap Yayasan Universitas Al Washliyah (UNIVA) Medan \\ Email :muhlizarsh11@gmail.com
}

\begin{abstract}
ABSTRAK
Salah satu tujuan didirikannya Negara adalah untuk memberikan kesejahteraan bagi rakyatnya, meningkatkan harkat dan martabat rakyat untuk menjadi manusia seutuhnya. Demikian juga Negara Republik Indonesia sebagai Negara merdeka dan berdaulat mempunyai tujuan dalam menjalankan pemerintahannya. Pembangunan di segala bidang dilakukan untuk membentuk masyarakat adil dan makmur berdasarkan Pancasila dan Undang-undang Dasar 1945. Namun diantara peraturan-peraturan tersebut terdapat hal-hal yang tidak konsisten, sehingga tidak menutup kemungkinan terjadinya penghindaran yang dilakukan wajib pajak, sebagaimana yang terjadi atas seperti pajak restoran. Dalam penghindaran pajak ini, wajib pajak tidak secara jelas melanggar undang-undang sekalipun kadang-kadang dengan jelas menafsirkan undang-undang tidak sesuai dengan maksud dan tujuan pembuat undang-undang. Metode pelaksanaan penyuluhan hukum yang kami lakukan yaitu dengan melakukan beberapa tahapan yaitu : persiapan, materi kegiatan, metode pelaksanaan evaluasi dan penyusunan laporan. Kegiatan pengabdian pada masyarakat ini akan dikemas dalam bentuk Penyuluhan. Dalam penyampaian berbagai materi kegiatan, dilakukan dengan cara sebagai berikut: pertama disampaikan ceramah, kemudian dilanjutkan dengan diskusi. Pemungutan pajak Restoran merupakan suatu rangkaian kegiatan mulai dari penghimpunan data objek pajak restoran dan subjek pajak restoran, dengan penentuan besarnya pajak restoran yang terutang sampai kegiatan menerima pembayaran pajak restoran tersebut dari wajib pajak. Dari pelaksanaan pengabdian pada masyarakat yang telah dilaksanakan yaitu dengan kegiatan penyuluhan hukum di prodi ilmu hukum, dapat disimpulkan bahwa masih minimmnya pengetahuan mahasiswa/i tentang perserta wajib pajak dan bentuk-bentuk yang terkenak pajak. Ole karena itu dengan penyuluhan hukum ini diharapkan mahasiswa/i akan memiliki pengetahuan dan pemahaman Perda 5 tahun 2011 tentang pajak restoran tersebut. Terkait masih kurangnya pemahaman mahasiswa/i tentang pajak restoran dan Perda 5 Tahun 2011 oleh karena itu tetap diperlukan penyuluhan hukum, lokakarya maupun seminar yang bekelanjutan.
\end{abstract}

Kata Kunci : Pajak Restoran, Mahasiswa

\begin{abstract}
One of the goals of the establishment of the State is to provide welfare for its people, improve the dignity of the people to become a whole person. Likewise, the Republic of Indonesia as an independent and sovereign state has a purpose in running its government. Development in all fields is carried out to form a just and prosperous society based on Pancasila and the 1945 Constitution. However, among these regulations there are things that are inconsistent, so as not to rule out the possibility of avoidance by taxpayers, as happened for such restaurant tax. In this tax avoidance, taxpayers do not clearly violate the law even though sometimes clearly interpreting the law is not in accordance with the intent and purpose of the legislator. The method of implementing legal counseling that we do is to do several stages, namely: preparation, activity material, method of implementation of evaluation and report preparation. This community service activity will be packaged in the form of Counseling. In the delivery of various activity material, it is carried out in the following way: first the lecture is delivered, then continued with discussion. Restaurant tax collection is a series of activities starting from the collection of restaurant tax object data and restaurant tax subjects, by determining the amount of restaurant tax payable until the activity receives the restaurant tax payment from the taxpayer. From the implementation of community service that has been carried out namely with legal counseling activities in the law study program, it can be concluded that there is still a lack of knowledge of students about taxpayer participants and
\end{abstract}


forms that are taxable. Therefore, with this legal counseling, it is expected that students will have the knowledge and understanding of Regional Regulation 5 of 2011 concerning the restaurant tax. Regarding the lack of understanding of students about restaurant taxes and Regional Regulation 5 of 2011 , it is necessary to continue legal counseling, workshops and seminars that are sustainable.

Keywords: Restaurant Taxes, Students

\section{PENDAHULUAN}

Salah satu tujuan didirikannya Negara adalah untuk memberikan kesejahteraan bagi rakyatnya, meningkatkan harkat dan martabat rakyat untuk menjadi manusia seutuhnya. Demikian juga Negara Republik Indonesia sebagai Negara merdeka dan berdaulat mempunyai tujuan dalam menjalankan pemerintahannya. Pembangunan di segala bidang dilakukan untuk membentuk masyarakat adil dan makmur berdasarkan Pancasila dan Undang-undang Dasar 1945.Untuk mencapai tujuan tersebut dalam melaksanakan tugas pemerintahan dan pembangunan senantiasa suatu negara memerlukan beberapa unsur pendukung, salah satunya adalah tersedianya sumber penerimaan yang memadai dan dapat diandalkan. Sumber-sumber penerimaan ini sangat penting untuk menjalankan kegiatan dari masing-masing tingkat pemerintahan, karena tanpa adanya penerimaan yang cukup maka program-program pemerintah tidak akan berjalan secara maksimal.

Apabila pemerintah Daerah melaksanakan fungsinya secara efektif, dan diberikan kebebasan dalam pengambilan keputusan penyediaan pelayanan di sektor publik, maka mereka harus didukung sumber-sumber keuangan yang memadai baik yang berasal dari Pendapatan Asli Daerah (PAD), Pinjaman, maupun dana Perimbangan dari Pemerintah Pusat. ${ }^{1}$

$\begin{array}{cccr} & \text { Machfud } & \text { Sidik, Makalah } \\ \text { Seminar } & \text { Nasional, } & \text { "Desentralisasi }\end{array}$

salah $\begin{array}{rrr}\text { Pajak } & \text { Daerah merupakan } \\ \text { satu } & \text { sumber } & \text { pendapatan }\end{array}$ salah satu sumber pendapatan daerah dari pendapatan asti daerah, menurut Pasal 8 Undang-Undang Nomor 33 Tahun 2004 bersambung dengan Pasal 158 ayat (1) UndangUndang Nomor 32 Tahun 2004, ditetapkan dengan Undang-Undang, yang pelaksanaanya di daerah diatur lebih lanjut dengan Peraturan Daerah.

Perbedaan mendasar antara pajak dan retribusi adalah terletak pada timbal balik langsung. Untuk pajak tidak ada timbal balik langsung kepada para pembayar pajak, sedangkan untuk retribusi ada timbal balik langsung kepada pembayar retribusi. Pajak daerah dapat diartikan biaya yang harus dikeluarkan seseorang atau suatu badan untuk menghasilkan pendapatan disuatu daerah, karena ketersediaan berbagai sarana dan prasarana publik yang dinikmati semua orang tidak mungkin ada tanpa adanya biaya yang dikeluarkan dalam bentuk pajak tersebut. Pajak merupakan pungutan yang bersifat memaksa berdasarkan perundang-undangan yang berlaku.

Berdasarkan Undang-Undang Nomor 28 Tahun 2009 tentang Pajak Daerah dan Retribusi Daerah, jenis-jenis pajak daerah yang boleh dipungut oleh daerah adalah sebagai berikut :

1. Pajak Provinsi terdiri dari :

a. Pajak Kendaraan Bermotor;

Fiskal, Kebijakan, Implementasi dan Pandangan ke Depan Perimbangan Keuangan Pusat dan Daerah”, Yogyakarta, 20 April 2002, hlm.5. 
b. Bea Balik Nama Kendaraan Bermotor;

c. Pajak Bahan Bakar Kendaraan Bermotor;

d. Pajak air permukaan; dan

e. Pajak Rokok.

2. Pajak Kota Kabupaten/Kota, terdiri dari :

a. Pajak Hotel;

b. Pajak Restoran;

c. Pajak Hiburan;

d. Pajak Reklame;

e. Pajak Penerangan Jalan;

f. Pajak Mineral Bukan Logam Dan Batuan;

g. Pajak Parkir,

h. Pajak air Tanah;

i. Pajak Sarang Burung Walet;

j. Pajak Bumi dan Bangunan Perdesaan Dan Perkotaan ; dan

k. Bea Perolehan Hak Atas Tanah dan Bangunan.

Dalam hal ini Kota Medan telah menetapkan Peraturan Daerah Kota Medan Nomor 12 Tahun 2003 tentang Pajak Daerah dan Perda Kota Medan Nomor 5 Tahun 2011 Tentang Pajak Restoran,yang sebagai dasar hukum pelaksanaan operasional di daerah.

Namun diantara peraturanperaturan tersebut terdapat hal-hal yang tidak konsisten, sehingga tidak menutup kemungkinan terjadinya penghindaran yang dilakukan wajib pajak, sebagaimana yang terjadi atas seperti pajak restoran. Penghindaran pajak terjadi sebelum SKP keluar. Dalam penghindaran pajak ini, wajib pajak tidak secara jelas melanggar undang-undang sekalipun kadangkadang dengan jelas menafsirkan undang-undang tidak sesuai dengan maksud dan tujuan pembuat undangundang. Perbuatan dengan cara sedemikian rupa sehingga perbuatan- perbuatan yang dilakukan tidak terkena pajak. Biasanya dilakukan dengan memanfaatkan kekosongan atau ketidak jelasan undang-undang. Hal inilah yang memberikan dasar potensial penghindaran pajak secara yuridis. Celah undang-undang merupakan dasar potensial penghindaran pajak secara yuridis.

Hal ini cukup menarik untuk diteliti, berkaitan dengan pengaturan sistem pemungutan pajak daerah apakah sudah sejalan dengan ketentuan yang telah ditetapkan dalam undang-undang.

\section{METODE PELAKSANAAN}

Metode pelaksanaan penyuluhan hukum yang kami lakukan yaitu dengan melakukan beberapa tahapan yaitu:

Langkah-langkah dan tahapan pemecahan masalah yang akan diterapkan dalam kegiatan ini mencakup :

1. Persiapan

Melakukan penjajakan terhadap pelaksanaan kegiatan penyuluhan hukum ini pada khalayak sasaran yaitu mahasiswa/i yang di prodi ilmu hukum Universitas Al Washliyah. Selanjutnya hasil penjajakan dipergunakan untuk penyusunan materi kegiatan dan jadwal kegiatan, Penentuan mitra atau khalayak sasaran.

2. Materi Kegiatan

Perencanaan materi kegiatan yang akan disampaikan oleh Narasumber meliputi : 


\begin{tabular}{|l|l|c|l|}
\hline No & \multicolumn{1}{|c|}{ Judul Materi } & Pemateri & \multicolumn{1}{|c|}{ Pendamping } \\
\hline 1 & $\begin{array}{l}\text { Pemahaman terhadap Perda No. 5 } \\
\text { Tahun 2011 tentang Pajak Restoran }\end{array}$ & $\begin{array}{c}\text { Tim } \\
\text { Pengusul }\end{array}$ & Pembantu \\
& Dekan III/ Staf \\
\hline 2 & Tanya jawab dan Diskusi & Tim & Pembantu \\
& & Pengusul & Dekan III/ Staf \\
\hline
\end{tabular}

3. Metode pelaksanaan

Metode pelaksanaan penyuluhan hukum akan dilakukan melalui beberapa cara antara lain: Melalui metode Ceramah. Metode ini ceramah ini akan diberikan langsung hadapan masiswa di tinggkat bawah oleh pemateri selaku mitra sesuai dengan tema yang telah ditentukan Diskusi dan tanya jawab.

4. Evaluasi

Evaluasi terhadap pelaksanaan kegiatan ini dilakukan baik terhadap proses maupun hasil yang didasarkan pada beberapa aspek, yaitu :

a. Kehadiran peserta

b. Keaktifan peserta

c. Relevansi

d. Akseptabilitas

e. Ketepatgunaan,

f. Dampak jangka panjang

g. Kuis.

5. Penyusunan Laporan

Penyusunan laporan dilakukan terhadap seluruh kegiatan mulai dari persiapan, pelaksanaan sampai evaluasi, dengan berpedoman pada ketentuan yang berlaku.

\section{HASIL DAN PEMBAHASAN}

Kegiatan pengabdian pada masyarakat ini akan dikemas dalam bentuk Penyuluhan. Dalam penyampaian berbagai materi kegiatan, dilakukan dengan cara sebagai berikut: pertama disampaikan ceramah, kemudian dilanjutkan dengan diskusi. Kegiatan pengabdian pada masyarakat ini dilakukan dengan tahapan sebagai berikut: pertama, persiapan. Pada tahap ini akan dilakukan penentuan lokasi kegiatan, jumlah peserta dan hari serta tanggal kegiatan. Tahap berikutnya menyebarkan undangan dan konfirmasi kehadirannya dalam kegiatan ini.

Kedua, pelaksanaan kegiatan. Kegiatan direncanakan berlangsung selama satu hari penuh, dengan jumlah peserta kurang lebih 45 orang, setelah itu dilakukan penyusunan laporan dan proses administrasi penyampaian laporan kegiatan. Kegiatan Penyuluhan Hukum ini dilaksanakan Di Prodi Ilmu Hukum Universitas Al Washliyah (UNIVA) Medan.

Menurut Undang-undang Nomor 28 tahun 2007 Tentang Ketentuan Umum dan Tata Cara Perpajakan Pasal 1 ayat 1 , Pajak adalah kontribusi wajib kepada negara yang terutang oleh orang pribadi atau badan yang bersifat memaksa berdasarkan UndangUndang, dengan tidak mendapatkan imbalan secara langsung dan digunakan untuk keperluan Negara sebagai tujuan kemakmuran rakyat.

Pada hakekatnya pengertian pajak berbeda-beda tergantung dari sudut pandang mana kita memandang masalah pajak ini, namun substansi dan tujuannya sama. Sampai saat ini tidak ada pengertian pajak yang sifatnya universal, maka masingmasing sarjana yang melakukan kajian terhadap pajak memberikan pengertian sendiri. Para ahli dalam 
bidang perpajakan yang memberikan batasan atau definisi yang berbeda-beda mengenai pajak, namun demikian berbagai definisi tersebut mempunyai inti atau tujuan yang sama dan ada beberapa definisi yang diungkapkan oleh para pakar antara lain:

1. P.J.A. Adriani (pernah menjabat guru besar dalam hukum pajak pada Universitas Amsterdam, kemudian Pemimpin International Bureau of Fiscal Documentation, juga di Amsterdam) yang dalam R. Santoso Brotodihardjo, dikemukakan sebagai berikut: ${ }^{2}$

"Pajak adalah iuran kepada negara (yang dapat dipaksakan) yang terutang oleh yang wajib membayarnya menurut peraturan- peraturan, dengan tidak mendapat prestasi-kembali, yang langsung dapat ditunjuk, dan yang gunanya adalah untuk membiayai pengeluaranpengeluaran umum berhubung dengan tugas negara untuk menyelenggarakan

pemerintahan."

Kesimpulan yang dapat ditarik dan definisi tersebut adalah, bahwa Adriani memasukkan pajak sebagai pengertian yang dianggapnya sebagai suatu species ke dalam genus pungutan (jadi, pungutan adalah lebih luas).

Dalam definisi ini titik berat diletakkan pada fungsi budgeter dari pajak, sedangkan pajak masih mempunyai fungsi lain yang tidak kalah pentingnya, yaitu fungsi mengatur. Bahwa

2 R. Santoso Brotodihardjo, Pengantar Ilmu Hukum Pajak, PT. Refika Aditama, Bandung. Cet Pertama Edisi Keempat, 2003, hlm.2. yang dimaksud dengan tidak mendapat prestasi-kembali dari negara ialah prestasi khusus yang erat hubungannya dengan pembayaran "iuran" itu. Prestasi dari negara, seperti hak untuk mempergunakan jalan-jalan umum, perlindungan dan penjagaan dari pihak polisi dan tentara, sudah barang tentu diperoleh oleh para pembayar pajak itu, tetapi diperolehnya itu tidak secara individual dan tidak ada hubungannya langsung dengan pembayaran itu. Buktinya: orang yang tidak membayar pajak pun dapat pula mengenyam kenikmatannya.

2. Definisi Prof. Dr. Rochmat Soemitro, S.H. dalam bukunya Dasar Dasar Hukum Pajak dan Pajak Pendapatan adalah sebagai berikut: ${ }^{3}$

"Pajak adalah iuran rakyat kepada kas negara herdasarkan undang- undang (yang dapat dipaksakan) dengan tidak mendapat jasa-jasa timbal (kontra-prestasi), yang langsung dapat ditunjukkan dan yang digunakan untuk membayar pengeluaran umum", dengan penjelasan sebagai berikut: "Dapat dipaksakan"

Artinya: bila utang pajak tidak dibayar, utang itu dapat ditagih dengan menggunakan kekerasan, seperti surat paksa dan sita, dan juga penyanderaan; terhadap pembayaran pajak, tidak dapat ditunjukkan jasa timbal balik tertentu, seperti halnya dengan retribusi. Yang tersimpul dalam berbagai definisi selain definisi Dr. Soeparman yang ${ }^{3}$ R. Santoso Brotodihardjo, Op. Cit, 
memang membuka ide baru itu adalah:

$$
\begin{aligned}
& \text { 1. Pajak dipungut } \\
& \text { bendasarkan/dengan kekuatan } \\
& \text { undang-undang serta aturan } \\
& \text { pelaksanaannya. } \\
& \text { 2. Dalam pembayaran pajak } \\
& \text { tidak dapat ditunjukkan } \\
& \text { adanya kontraprestasi individual } \\
& \text { oleh pemerintah. }
\end{aligned}
$$

Pemungutan pajak Restoran merupakan suatu rangkaian kegiatan mulai dari penghimpunan data objek pajak restoran dan subjek pajak restoran, dengan penentuan besarnya pajak restoran yang terutang sampai kegiatan menerima pembayaran pajak restoran tersebut dari wajib pajak. Untuk itu wajib pajak terlebih dahulu melaporkan jenis usahanya kepada Dinas Pendapatan Daerah dengan prosedur sebagai berikut $:^{4}$

1) Pengukuhan wajib Pajak

2) Pendaftaran dan Pendataan

3) Pelaporan Pajak dan Surat Pemberitahuan Pajak Daerah (STPD)

4) Penetapan Pajak Restoran

5) Pembayaran Pajak Restoran

6) Penagihan Pajak Restoran

\section{Pelaksanaan pemungutan pajak restoran}

\section{A. Tata Cara pemungutan pajak restoran \\ Dalam Perda Nomor. 15}

Tahun 2011 tentang Pajak Restoran dalam BAB VII Tata Cara Pemungutan Pajak dikatakan:

1. Pemungutan pajak tidak dapat di borongkan artinya, seluruh proses kegiatan pemungutan pajak restoran tidak dapat

${ }^{4}$ Perda Kota Medan No. 5 Tahun 2011 BAB VI Pendataan dan Penetapan Pajak Pasal 11. diserahkan kepada pihak ketiga.

2. Pajak dipungut berdasarkan ketetapan wajib pajak atau dibayar sendiri oleh wajib pajak.

3. Wajib pajak dalam memenuhi kewajiban pajaknya yang di pungut dengan menggunakan Surat Ketetapan Pajak Daerah (SKPD) atau dokumen lain yang di persamakan.

Adapun sistem dan prosedur tata cara pemungutan pajak restoran adalah sebagai berikut:

1. Pendataan dan Pendaftaran

2. Penetapan (menerbitkan SKPD)

3. Pembukuan dan Pelaporan (menghitung besar pajak)

4. Pemungutan (pihak dispenda Kota Medan)

Dalam artinya lebih lanjut bahwa kegiatan dan pendaftaran dan pendataan wajib pajak restoran yang dilakukan oleh petugas secara optimal akan menetapkan target penerimaan yang ideal karena sudah dipertimbangkan berdasarkan dengan data-data yang ada dan tentunya unit kerja sebagai penetapan akan menerbitkan Surat Ketetapan Pajak Sementara (SKPS) terlebih dahulu.

Dengan demikian untuk meningkatkan Pendapatan Asli Daerah (PAD) Kota Medan dari sektor pajak restoran ini khususnya melalui kegiatan penerimaan yang dilakukan, petugas yang telah ditunjuk haruslah bekerja seoptimal mingkin, disamping itu diminta agar wajib pajak meningkatkan kesadaranya untuk membayar pajak karena keberhasilan untuk pencapaian target tidak akan tercapai tanpa adanya hubungan kerjasama dalam hal ini petugas kolektor dengan masyarakat. 


\section{B. Masalah-masalah yang terjadi dalam pemungutan pajak restoran}

Dalam pelaksanaan tugas sebagai badan pemungut pajak daerah yang di tunjuk oleh Pemerintah Daerah Kota Medan belumlah berjalan sebagaimana yang di inginkan. Ini diakibatkan oleh berbagai faktor-faktor, baik faktor internal maupun faktor eksternal.

Dari segi fakor intenal kurangnya pantauan atau pendataan yang dilakukan petugas-petugas lapangan terhadap wajib pajak atau objek pajak yang ada, sehingga belum terdatanya keseluruhan objek pajak yang ada. Tekait pengawasan terhadap penerapan tarif pajak restoran, sehingga wajib pajak terkesan bisa melakukan negosiasi pengurangan tarif di saat pemungutan. Didalam pemberian sanksi sebagaimana diatur dalam perda Nomor 5 Tahun 2011, belum terimplementasi seutuhnya, artinya hukum terhadap wajib pajak yang melakukan pelanggaran belum di terapkan seoptimal mungkin, sehingga wajib pajak tidak diberikan sanksi.

Faktor eksternal yaitu berasal dari peseta wajib pajak belum mengetahui arti penting pajak, sehingga wajib pajak enggan membayar pajaknya.dan belum adanya kesadaran wajib pajak dalam mematuhi peraturan daerah atau ketentuan yang telah ditetapkan, sehingga banyaknya wajib pajak yang melanggar peraturan tersebut.

Upaya-upaya yang dilakukan untuk mensukseskan teralisasinya perda 5 tahun 2011 melaksanakan sosialisasi baik yang langsung maupun tidak langsung untuk meningkatkan pemahaman wajib pajak betapa pentingnya membayar pajak. Dan meningkatkan Sumber Daya Manusia (SDM) dari segala lini untuk mengawasi Perda yang telah ditetapkan.

\section{KESIMPULAN}

Dari pelaksanaan pengabdian pada masyarakat yang telah dilaksanakan yaitu dengan kegiatan penyuluhan hukum di prodi ilmu hukum, dapat disimpulkan bahwa masih minimmnya pengetahuan mahasiswa/i tentang perserta wajib pajak dan bentuk-bentuk yang terkenak pajak. Ole karena itu dengan penyuluhan hukum ini diharapkan mahasiswa/i akan memiliki pengetahuan dan pemahaman Perda 5 tahun 2011 tentang pajak restoran tersebut. Terkait masih kurangnya pemahaman mahasiswa/i tentang pajak restoran dan Perda 5 Tahun 2011 oleh karena itu tetap diperlukan penyuluhan hukum, lokakarya maupun seminar yang bekelanjutan.

\section{Daftar Pustaka}

Bukhori, "Pengantar Hukum Pajak", Edisi Revisi, Cet. IV, PT Raja Grafindo Persada, Jakarta, 2002.

Erly Suandi, Hukum Pajak, Salemba Empat, Jakarta, 2000.

H.A.W. Widjaja, Otonomi Daerah dan Daerah Otonomi, Raja Grafindo Persada, Jakarta, 2002.

Machfud Sidik, 2002, Makalah Seminar Nasional, "Desentralisasi Fiskal, Kebijakan, Implementasi dan Pandangan ke Depan Perimbangan Keuangan Pusat dan Daerah”, Yogyakarta.

R. Santoso Brotodihardjo, 2003 Pengantar Ilmu Hukum Pajak, PT. Refika Aditama, Bandung. Cet Pertama Edisi Keempat. 
Amaliah: Jurnal Pengabdian Kepada Masyarakat Volume 1 No. 2 November 2017

Undang-Undang Dasar RI Tahun

1945

Undang-Undang Nomor 28 Tahun

2009 Tentang Pajak Daerah dan

Retribusi Daerah

Perda Kota Medan No. 5 Tahun 2011 